\title{
PENGGUNAAN MEDIA TABEL TULANG NAPIER DALAM UPAYA MENGATASI KESULITAN BELAJAR MATEMATIKA SISWA PADA OPERASI HITUNG PERKALIAN
}

\author{
Sri Wulan Anggraeni \\ PGSD Fakultas Keguruan dan Ilmu Pendidikan \\ Universitas Buana Perjuangan \\ wulan.anggraeni@ubpkarawang.ac.id
}

\begin{abstract}
Characteristics of a child who has difficulty learning math is characterized by his inability to solve problems related to mathematical components. This research was conducted in class V SDN Muktiwari 02 because the students' ability in calculating the multiplication is still low. The use of bone napier in teaching multiplication is very interesting for students, both the clever and the less. The method used in this research is Action Class Action model of Kemmis and Mc. Taggart. This research was done twice the action. The results showed that the mathematics learning using napier bone table media can improve the students' mathematics learning outcomes. It is proven by the activity and the result of learning to write poetry of students on pre-cycle condition with an average score of 61.67. After doing the action by using media table of bone napier experience improvement that is on first cycle with average value 72,7 and second cycle average value 83,7. Therefore, learning by using napier bone table media, can improve the learning outcomes of mathematics.
\end{abstract}

\section{Keywords: Media Table of Bone Napier, Difficulty Learning Math}

\begin{abstract}
Abstrak: Karakteristik anak yang mengalami kesulitan belajar matematika ditandai oleh ketidakmampuannya dalam memecahkan masalah yang berkaitan dengan dengan komponen-komponen matematika. Penelitian ini dilakukan di kelas V SDN Muktiwari 02 karena kemampuan siswa dalam menghitung perkalian masih rendah. Penggunaan tulang napier dalam mengajarkan perkalian sangat menarik bagi siswa, baik yang pandai maupun yang kurang. Metode yang digunakan dalam penelitian ini adalah Penelitian Tindakan Kelas model Kemmis dan Mc. Taggart. Penelitian ini dilakukan sebanyak dua kali tindakan, Hasil penelitian menunjukkan bahwa pembelajaran matematika dengan menggunakan media table tulang napier dapat meningkatkan hasil belajar matematika siswa. Terbukti dengan aktivitas dan hasil belajar menulis puisi siswa pada kondisi awal pra siklus dengan nilai rata-rata 61,67. Setelah dilakukan tindakan dengan menggunakan media tabel tulang napier mengalami peningkatan yaitu pada siklus pertama dengan nilai rata-rata 72,7 dan nilai rata-rata siklus kedua 83,7. Oleh karena itu, Pembelajaran dengan menggunakan media tabel tulang napier, dapat meningkatkan hasil belajar matematika.
\end{abstract}

\section{Kata Kunci: Media Tabel Tulang Napier, Kesulitan Belajar Matematika}




\section{PENDAHULUAN}

Matematika sebagai salah satu mata pelajaran yang diajarkan di sekolah dasar mempunyai posisi yang sangat penting, sebab di samping dapat memberi bekal kemampuan berhitung, juga dapat memberi bekal kemampuan bernalar. Pada pendidikan dasar, matematika tergolong mata pelajaran yang dirasakan sulit bagi siswa, karena matematika ditinjau dari segi objeknya bukanlah merupakan objek konkret, tetapi merupakan benda pikiran. Apalagi sistem pembelajaran konvensional yang statis dan rutin yang sering digunakan oleh guru-guru, seperti pemberian tugas mengerjakan latihan soal dengan contoh-contoh yang ada dalam buku pegangan siswa. Dengan pola pembelajaran seperti itu, jelas akan membawa siswa ke arah kebosanan dan berdampak pada ketidaksukaan pada matematika. Mereka menganggap bahwa matematika hanyalah bagian dari pelajaran yang ada di kelas, mereka tahu hanya sebatas konsep, dan hanya dipelajari di dalam kelas. Hal ini dapat mengakibatkan dampak yang sangat buruk terhadap sikap dan minat siswa dalam penguasaan pemahaman berhitung pada tingkat selanjutnya. Mereka beranggapan bahwa matematika adalah ilmu yang tidak ada hubungannya dengan aspek lain. Bahkan mereka tidak tahu untuk apa belajar matematika.

Salah satu kemampuan matematika yang harus dikuasai siswa kelas V SD adalah mengoperasikan perkalian bilangan cacah. Bagi sebagian guru SD, mengajarkan materi matematika yang berkaitan dengan perkalian bilangan cacah bukanlah soal yang mudah. Konsep perkalian merupakan konsep dasar atau prasyarat untuk mempelajari konsep-konsep lainnya, sehingga harus benar-benar dikuasai siswa.

Berdasarkan hasil observasi yang dilaksanakan pada tanggal 23 Januari 2017 di SDN. Muktiwari 02 Kecamatan Cibitung Kabupaten Bekasi. Menemukan permasalahan Pada mata pelajaran matematika bahwa siswa kurang antusias dalam mengikuti proses pembelajaran dan hasil belajar matematika siswa masih kurang dari KKM yaitu 75. Hal ini dikarenakan siswa masih menggunakan hapalan perkalian dan masih belum mengerti konsep perkalian sehingga jika siswa lupa, maka akan mempengaruhi hasil belajarnya dan ditemukan beberapa siswa menggunakan kalkulator dalam menghitung perkalian bilangan cacah, ini 
disebabkan karena siswa kurang percaya diri dengan kemampuannya. Selain itu, guru kurang mestimulus siswa dengan media pembelajaran, karena pada tahap usia sekolah dasar masih dalam tahap operasional konkret yang mana siswa masih membutuhkan benda konkret.dalam memahami sebuah konsep.

Di lihat dari permasalahan di atas, pembelajaran matematika pada operasi perkalian akan lebih baik lagi jika disajikan dengan menggunakan media pembelajaran yang menarik agar siswa tidak kesulitan dalam memahami konsep perkalian. Media pembelajaran dalam penelitian ini adalah media tabel tulang napier.

Penggunaan tabel tulang napier dalam mengejarkan perkalian akan sangat menarik bagi siswa baik yang pandai maupun yang kurang. "Alat peraga tulang napier dimaksud adalah suatu alat peraga yang diciptakan oleh Jhon Napier pada tahun 1617, seorang ahli matematika dari Skotlandia" (Direktorat Pendidikan TK dan SD, 2004: 23).

Alat peraga tulang napier adalah suatu alat yang ditemukan oleh Jhon Napier (1550-1617), dan pertamakali dipublikasikan ke khalayak ramai lewat bukunya Rabdologiae (Metode numerik dengan Bantuan tongkat-tongkat kecil). Karena pemakaiannya yang meluas, walhasil tongkat-tongkat kecil yang jadi alat bantu dari metode ini dibuat dalam berbagai ukuran, kemasan dan dari berbagai bahan. Yang paling umum memang terbuat dari tulang. Tapi ada juga yang sempat membuat tongkat Napier ini dari gading gajah. Jadi alat peraga tulang napier adalah suatu alat yang digunakan oleh Jhon Napier dalam menyelesaikan soal dengan bantuan tongkat-tongkat kecil. 


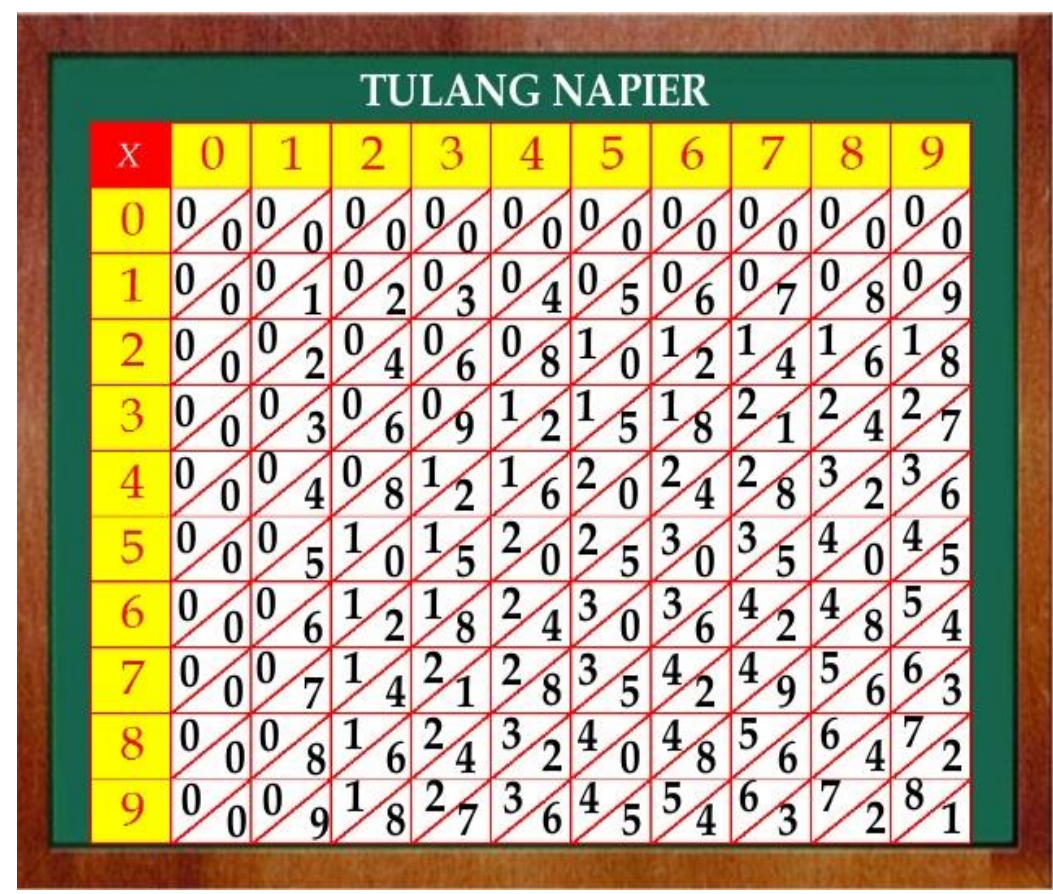

Gambar 1

Perkalian Tulang Napier

(Direktorat Pendidikan TK dan SD, 2004: 24)

\section{METODE PENELITIAN}

Penelitian yang digunakan adalah penelitian tindakan kelas (classroom action research). Dengan menggunakan penelitian tindakan kelas, seorang guru dapat memperbaiki kinerjanya dan dapat memecahkan masalah-masalah yang terjadi di dalam kelas dengan cara melihat kembali apa yang sudah dilakukannya selama di dalam kelas.

Variable yang digunakan dalam penelitian ini adalah media table tulang napier sebagai variable bebas dan hasil belajar matemtika sebagai variable terikat. Media table tulang napier sebagai treatment dalam mengatasi kesulitan belajar matematika pada operasi hitung perkalian. Dan tes operasi hitung perkalian sebagai penentu keberhasilan pembelajaran matematika.

Adapun desain perbaikan pembelajaran dengan menggunakan alur penelitian tindakan kelas sebagai berikut. 


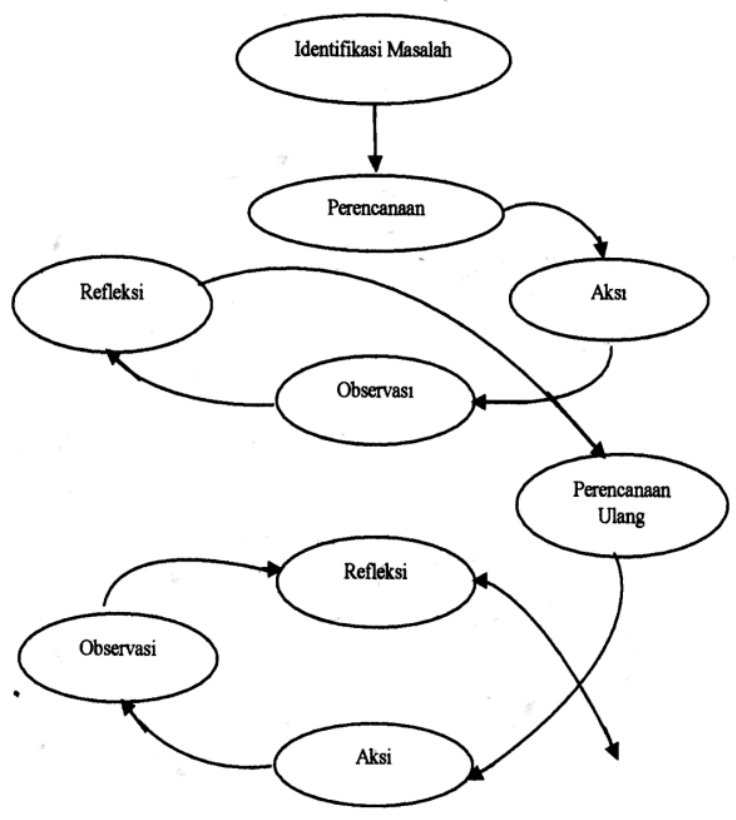

Gambar 2

Alur Penelitian Tindakan Kelas Menurut Taggart (Kasbolah, 1998: 15)

Tahapan yang dijelaskan pada gambar 2 alur penelitian tersebut akan dipergunakan sebagai langkah dalam penelitian yaitu dilaksanakan melalui proses pengkajian berdaur, yang terdiri dari empat tahap, yaitu merencanakan, melakukan tindakan, mengamati, dan melakukan refleksi.

Dalam merencanakan empat tahapan tersebut, yang perlu dilakukan terlebih dahulu adalah identifikasi masalah yaitu merumuskan masalah yang akan dijadikan sebagai objek penelitian, setelah masalah dirumuskan langkah selanjutnya adalah menentukan perencanaan yaitu proses penyusunan rencana tindakan yang akan dilakukan untuk memecahkan masalah yang dilakukan secara sistematik, kemudian tahap pelaksanaan yang dilakukan peneliti sesuai dengan rancangan yang telah dibuat sebelumnya, sebagai upaya perbaikan dalam proses pembelajaran. Pada saat proses pembelajaran, peneliti melakukan observasi guna mengamati proses, hasil ataupun dampak dari pengembangan tindakan sebelumnya, baik terhadap siswa dan kinerja guru dalam proses pembelajaran, dan juga suasana kelas secara keseluruhan. Hasil observasi yang telah diamati selanjutnya digunakan untuk menata kembali langkah-langkah refleksi dan revisi pada perencanaan tindakan selanjutnya. 
Penelitian tindakan kelas ini dilaksanakan pada pembelajaran matematika khususnya pada operasi hitung perkalian di kelas V SDN. Muktiwari 02 kecamatan Cibitung kabupaten Bekasi. Subyek penelitian ini adalah siswa kelas V SDN. Muktiwari 02 Kecamatan Cibitung Kabupaten Bekasi Tahun Pelajaran 2016/2017, berjumlah 20 orang.

Data penelitian diperoleh dari hasil tes operasi hitung perkalian yang digunakan untuk mengetahui peningkatan hasil belajar matematika siswa mengenai informasi tentang kemampuan-kemampuan yang berhubungan dengan operasi hitung perkalian dengan menggunakan media table tulang napier. Observasi merupakan salah satu teknik pengumpulan data yang sangat menentukan dalam pelaksanaan penelitian tindakan kelas. Lembar observasi digunakan untuk menganalisis dan merefleksi setiap siklus untuk perbaikan siklus berikutnya. Hal yang direfleksikan yaitu proses pembelajaran aktivitas guru dan siswa.

Analisis data dalam penelitian ini menggunakan analisis kualitatif, di mana analisis dilakukan secara terus menerus dari awal sampai akhir pelaksanaan penelitian. Analisis kualitatif untuk memberikan interprestasi secara konseptual terhadap kinerja guru, yang berupa kemampuan guru dalam menerapkan pembelajaran operasi perkalian dengan menggunakan media table tulang napier, aktivitas peserta didik, serta pola interaksi dalam proses pembelajaran.

Data yang telah terkumpul kemudian dikategorisasikan. Kategorisasi data dilakukan dengan mengelompokkan sebagai berikut: a) berupa informasi tentang latar fisik kelas, para pelaku yang dalam hal ini adalah guru dan peserta didik, b) meliputi informasi tentang interaksi edukatif antara guru dan peserta didik, peserta didik dengan peserta didik, maupun perubahan-perubahan yang terjadi selama proses pembelajaran berlangsung, c) meliputi informasi tentang tindakan para pelaku yaitu guru dan peserta didik.

\section{HASIL DAN PEMBAHASAN}

Tes hasil belajar yang telah dilakukan menunjukkan bahwa pemahaman siswa semakin meningkat. Ini dapat dilihat dari hasil tes siswa pada pra siklus, siklus I dan siklus II. Secara jelas dapat dilihat pada table berikut ini. 
Table 1

Rekapitulasi Jumlai Nilai Rata-rata Tes Per siklus

\begin{tabular}{|l|l|l|c|}
\hline No. & \multicolumn{1}{|c|}{ siklus } & \multicolumn{1}{|c|}{ Materi pokok } & Nilai rata-rata \\
\hline 1 & Pra siklus & $\begin{array}{l}\text { Perkalian bilangan 1 angka } \\
\text { dengan bilangan 2 angka }\end{array}$ & 61,67 \\
\hline 2 & Siklus I & $\begin{array}{l}\text { Perkalian bilangan 1 angka } \\
\text { dengan bilangan 2 angka }\end{array}$ & 72,7 \\
\hline 3 & Siklus II & $\begin{array}{l}\text { Perkalian bilangan 2 angka } \\
\text { dengan bilangan 2 angka }\end{array}$ & 83,7 \\
\hline
\end{tabular}

Melihat hasil seperti yang ditunjukkan pada siklus II, diperoleh nilai di atas 75 melebihi $50 \%$ siswa yang mendapat nilai di atas 75 ada 15 orang (75\%). Rata-rata kelas pada siklus II adalah 83,7. Jelas ini menggambarkan perkembangan prestasi siswa yang terus meningkat.Dengan penuh semangat siswa memperlihatkan kemajuan hasil tes yang telah dilakukan. Dari hasil kesimpulan pada tes pembelajaran yaitu:

1. Proses pembelajaran ditunjukkan siswa dari siklus I sampai siklus II semakin antusias dan meningkat.

2. Guru selalu memberikan arahan dan bimbingan dalam setiap pengerjaan soal yang diberikan.

3. Hasil positif dapat terlihat pada table hasil evaluasi yang ditunjukkan siswa, ini menggambarkan bahwa motivasi dan minat siswa menjadi lebih meningkat.

Pembelajaran perkaliam dengan menggunakan media table tulang napier, ternyata mampu menarik perhatian dan minat siswa. Siswa mampu mengidentifikasi masalah, sehingga siswa bukan hanya memiliki nilai yang baik saja, tetapi mampu memiliki konsep yang kuat. Dengan menggunakan media table tulang napier siswa lebih memperhatikan penjelasan guru dan bebas berkreasi. Siswa tidak hanya mendengarkan saja, tetapi dapat mengembangkan kreativitasnya dengan cara menggambar dan mewarnai table tulang napier sesuai selera mereka. Dari hasil tes yang telah dilakukan, dapat disimpulkan bahwa pemahaman siswa menjadi lebih meningkat.ini dapat dilihat dari prestasi yang telah dilakukan. 


\section{KESIMPULAN}

Berdasarkan analisis data dan hasil penelitian yang telah dipaparkan pada bab sebelumnya, peneliti menarik kesimpulan sebagai berikut:

1. Penggunaan media table tulang napier pada pemelajaran matematika konsep perkalian bilangan cacah dapat meningkatkan pemahaman siswa terhadap perkalian. Peningkatan pemahaman siswa dapat dilihat dari nilai tes evaluasi siswa dari setiap siklus menunjukkan peningkatan yang sangat signifikan.

2. Penggunaan media table tulang napier pada pembelajaran matematika di kelas V SDN Muktiwari 02 dapat meningkatkan minat siswa terhadap pembelajaran matematika. Penggunaan media table tulang napier pada pembeljaran matematika di kelas $\mathrm{V}$ dapat meningkatkan aktivitas siswa selama proses pembelajaran. Hal ini terlihat pada aktivitas siswa yang antusias dalam proses pembelajan. Siswa aktif dalam menjawab pertanyaan guru dan tidak malu saat maju ke depan kelas.

\section{DAFTAR PUSTAKA}

Aam. Pengertian Matematika. Tersedia online. http://id.shvoong.com/socialsciences/education/2118693-pengertian-matematika/.2011. Diakses pada tanggal 12 September 2016

Abidin, MZ. Pengertian Matematika. Tersedia online. http://www.masbied.com/2012/02/18/pengertian-matematika/. Diakses pada tanggal 12 desember 2012

Anitah, S.W, dkk. Strategi Pembelajaran di SD. Jakarta: Universitas Terbuka, 2009.

Aunurrahman. Belajar dan Pembelajaran. Bandung: Alfabeta, 2009.

Burhanuddin, TR. Pendekatan, Metode, dan Teknik Penelitian Pendidikan. Purwakarta: Program Pendidikan Guru Sekolah Dasar Universitas Pendidikan Indonesia. 2009.

Departemen Pendidikan Nasional. Kurikulum Tingkat Satuan Pendidikan. Jakarta, 2006

Direktorat Pendidikan Taman Kanak-kanak dan Sekolah Dasar. Model Pembelajaran Baca Tulis Hitung SD Perkalian Bilanangan Dua Angka dengan Bilangan satu Angka atau Bilangan Dua Angka.Jakarta: Departemen Pendidikan Nasioanal, 2004.

Jamaris, M. Kesulitan Belajar: Perspektif, Assessmen dan Penanggulangannya. Jakarta: Yayasan Penamas Murni, 2009. 
Kasbolah, K.E.S. Penelitian Tindakan Kelas. Jakarta: Depdikbud, 1998.

Madya, S. Teori dan praktek penelitian tindakan (action research). Bandung: alfabeta. 2007

Moleong. L. J. Metodelogi penelitian kualitatif. Bandung: remaja rosda karya. 2010.

Nuryani,

A. Meningkatkan

Pemahaman

Perkalian

Bilangan

Cacah

dengan

Menggunakan

Alat Peraga Benda-Benda Manipulatif. Bandung: Universitas Pendidikan Indonesia, 2011

Pustaka Sekolah. Pengertian Matematika. Tersedia online. http://www.pustakasekolah.com/pengertian-matematika.html.2012. Diakses pada tanggal 12 Desember 2012

Rahardjo, M. Metode Pengumpulan Data Penelitian Kualitatif. Tersedia Online. http://mudjiarahardjo.com/component/content/336.html?task=view. 2012. Diakes pada tanggal 14 Desember 2012.

Sanaky, H. Media Pembelajaran. Yogyakarta: Kaukaba Dipantara.2011.

Sangbahagia. Fungsi Pelajaran Matematika dan Tujuannya. Tersedia online. http://id.shvoong.com/social-sciences/education/2132429-fungsi-pelajaranmatematika-dan-tujuan/. 2011.Diakses pada tanggal 13 Desember 2012

Shadiq, F. Faktor-Faktor Penyebab Kesulitan Belajar Siswa. Tersedia online. http://fadjarp3g.files.wordpress.com/2007/09/aa-litansiswa_wartaguru_pdf. Diakses pada tanggal 11 Desember 2012

Sudjana, N dan Rivai, A. Media Pengajaran. Bandung: Sinar Baru Algensindo, 2010.

Sufanti, M. Strategi Pengajaran dan Sastra Indonesia. Surakarta: Yuma Pustaka, 2010.

Sujiono, Yuliani, N. Mengajar dengan Fortofolio. Jakarta: Indeks, 2010

Thoifuri. Menjadi Guru Inisiator. Semarang: Rasail, 2007. 
